\title{
ANALISIS DANA PERIMBANGAN KAITANNYA DENGAN PERCEPATAN LAJU PERTUMBUHAN EKONOMI KABUPATEN LOMBOK TIMUR NUSA TENGGARA BARAT TAHUN 2012-2016
}

\author{
Siti Fatimah ${ }^{1}$ \\ ${ }^{1}$ Dosen Fakultas Ekonomi dan Bisnis Unram, sitifatimah.unram@gmail.com
}

\begin{abstract}
ABSTRAK
Sejalan dengan arus pemberian kewenangan yang makin luas yang dimiliki tiap daerah dalam era otonomi daerah ini, maka peran dan fungsi pendapatan daerah melalui penggalian potensi masing-masing daerah menjadi sesuatu yang amat penting. Sebagai ilustrasi peran dana perimbangan menjadi sangat strategis dalam mendorong laju pertumbuhan ekonomi suatu daerah. Tujuan penelitian ini adalah untuk melihat bagaimana peranan dana perimbangan terhadap laju percepatan pertumbuhan ekonomi Kabupaten Lombok Timur terhitung sejak Tahun 2012-2016. Selanjutnya untuk mengukur berapa besar kontribusi dana perimbangan terhadap Total Pendapatan Daerah $(T P D)$ yang dikaitkan dengan laju percepatan pertumbuhan ekonomi (PDRB) Kabupaten Lombok Timur terhitung sejak Tahun 2012-2016.

Menurut tingkat eksplanasinya jenis penelitian ini termasuk penelitian deskriptif. Teknik pengumpulan data menggunakan studi kepustakaan (Library Research) dan penelitian lapangan (Field Research). Variabel yang digunakan dalam penelitian ini adalah Pendapatan Daerah, Dana Perimbangan, Pendapatan lain Yang Syah, Belanja Aparatur, Belanja Pelayanan Publik dan Belanja Bagi Hasil. Adapun alat analisis yang digunakan dalam penelitian ini menggunakan pendekatan rasio dengan membandingkan besarnya dana perimbangan dengan pendapatan daerah serta pendekatan PDRB (Product Domestic Ragional Brutto) serta komponen lainnya yang langsung terkait dengan laju pertumbuhan ekonomi kabupaten Lombok Timur.

Hasilnya adalah Dampak pengalokasian dana perimbangan terhadap laju percepatan pertumbuhan ekonomi Kabupaten Lombok Timur terhitung sejak Tahun 2012-2016 sangat besar. Rata-rata Laju pertumbuhan Kontribusi Dana Perimbangan Terhadap Pertumbuhan Ekonomi (PDRB) Atas Dasar Harga Konstan Tahun 2010 Kabupaten Lombok Timur Tahun 2012-2016 sebesar 9,85 persen dan Atas Dasar Harga Berlaku sebesar 11,36 persen. Artinya bahwa kontribusi dana perimbangan terhadap laju pertumbuhan ekonomi selama lima tahun di kabupaten Lombok Timur cukup signifikan
\end{abstract}

Kata Kunci : Dana Perimbangan

\begin{abstract}
In line of the authority which are owned by each region in the era of regional autonomy so the rule and function of regional income trough extracting potential of each region is very important, as an illustration the role of balance fund become strategic in the push the growth economic rate of region, the research aim is to see how the role of balance fund toward acceleration rate of economic growth east Lombok district since 2012-2016, to measure how high the contribution of fund balance toward total regional income which related to acceleration rate of economic growth east Lombok district since 2012-2016, this is descriptive research, data collecting technique use library research and field research variable done by regional income, fund balance, and other income, apparatus expenditure, service public expenditure, and profit sharing expenditure and analysis device ratio approach with compare the magnitude of fund balance with
\end{abstract}


regional income also PDRB approach, also other component related with rate of economic growth east Lombok district, research result is the average of contribution growth rate of fund balance toward economic growth (PDRB) on base constant price year 2010, east Lombok district year $2010-2016$ is $9.85 \%$ and current prices is $11.36 \%$ means that contribution fund balance toward rate of economic growth for five years in east Lombok district is significant enough.

\section{Keyword: Fund Balance}

\subsection{Latar Belakang}

\section{PENDAHULUAN}

Sejalan dengan arus pemberian kewenangan yang makin luas yang dimiliki tiap daerah dalam era otonomi daerah ini, maka peran dan fungsi pendapatan daerah melalui penggalian potensi masing-masing daerah menjadi sesuatu yang amat penting. Ini dimaksudkan karena kemampuan tiap daerah dalam menggali potensinya menjadi suatu indikator kinerja keuangan daerah dalam penerapan otonomi daerah. Oleh karenanya pendapatan asli daerah yang merupakan bagian dari pendapatan daerah hendaknya terus dikembangkan. Secara lebih konkrit unsur pendapatan dan belanja daerah dapat ditunjukkan melalui perkembangan Anggaran Pendapatan dan Belanja Daerah (APBD).

Dalam kenyataannya masih banyak pemerintah daerah yang menggantungkan sumber penerimaannya melalui bantuan pemerintah pusat. Padahal jika diamati secara priodik dari waktu ke waktu, pemerintah pusat juga selalu mengalami kesulitan dalam mendanai pengeluarannya, baik yang menyangkut pengeluaran belanja aparatur pemerintah maupun untuk belanja pelayanan publik. Terlebih sekarang dengan telah diberlakukannya otonomi daerah telah membawa pengaruh beban pemerintah pusat terhadap pemerintah daerah tidak semakin kecil. Oleh karenanya sekarang ini melalui pemberian kewenangan masing-masing daerah yang semakin luas diaharapkan setiap daerah dituntut agar dapat membiayai dirinya sendiri melalui optimalisasi sumber-sumber penerimaan yang dimiliki secara efektif dan efisien. Karena tolok ukur keberhasilan setiap pemerintah daerah kabupaten/kota dalam melaksanakan tugas-tugas pemerintahan, proses pembangunan daerah, dan pelayan publik akan sangat tergantung dari bagaimana pemerintah daerah mampu menggali setiap potensi daerah untuk kemudian mengatur dalam bentuk belanja aparatur pemerintah dan belanja pelayanan publik secara berimbang dan proforsional sesuai yang diamanatkan perundang-undangan yang berlaku.

Kebijakan pemberian otonomi daerah merupakan langkah strategis dalam dua hal. Pertama, otonomi daerah dan desentralisasi merupakan jawaban atas permasalahan lokal bangsa Indonesia berupa ancaman disintegrasi bangsa, kemiskinan, ketidakmerataan pembangunan, rendahnya kualitas hidup masyarakat, dan masalah pembangunan sumber daya manusia. Kedua, otonomi daerah dan desentralisasi merupakan langkah strategis bangsa Indonesia untuk menyongsong era globalisasi ekonomi dengan memperkuat basis perekonomian daerah. (Mardiasmo, 2002:59).

Terkait dengan fungsi dan tugas pemerintah daerah dalam era otonomi daerah akhir-akhir ini maka, tidak dapat dipungkiri lagi bahwa peranan identifikasi potensi dan sumber perolehan keuangan daerah menjadi sesuatu yang amat penting. Ini diharapkan akan mampu memberikan informasi yang lebih akurat mengenai alternatif sumber-sumber penerimaan daerah guna membiayai penyelenggaraan pemerintahan daerah. Secara implisit ketersediaan data mengenai perkembangan sumber-sumber penerimaan dan pengeluaran daerah dapat dijadikan bahan acuan pemerintah daerah dalam membuat perencanaan dan pola kebijakan pemerintah daerah terutama dalam pengelolaan keuangan daerah yang 
sekaligus dapat berfungsi sebagai bahan evaluasi sampai sejauhmana tingkat kemandirian dan desentralisasi fiskal daerah di era otonomi daerah sekarang ini. Selanjutnya akan ditunjukkan perkembangan Anggaran Pendapatan Kabupaten Lombok Timur selama lima tahun terakhir sesuai tabel di bawah ini.

Tabel 1.1. Realisasi PAD, Dana Perimbangan, Pendapatan Lain Yang Syah Kabupaten Lombok Timur Tahun 2012-2016 (Persentase/jutaan rupiah)

\begin{tabular}{|c|c|c|c|c|c|c|c|}
\hline Tahun & P A D & $\mathbf{\%}$ & $\begin{array}{c}\text { Dana } \\
\text { Perimbangan }\end{array}$ & $\mathbf{\%}$ & $\begin{array}{c}\text { Pendapatan } \\
\text { Lain Yang } \\
\text { Syah }\end{array}$ & $\mathbf{\%}$ & $\begin{array}{c}\text { Total } \\
\text { Pendapatan }\end{array}$ \\
\hline 1 & 2 & $3=2: 8$ & 4 & $5=4: 8$ & 6 & $7=6: 8$ & 8 \\
\hline 2012 & $88.007,7$ & 6,9 & $1.021 .767,6$ & 80,08 & $21.175,0$ & 1,66 & $1.276 .066,7$ \\
\hline 2013 & $97.249,1$ & 6,78 & $1.129 .526,7$ & 78,74 & $207.874,0$ & 14,5 & $1.434 .649,8$ \\
\hline 2014 & $180.308,2$ & 10,6 & $1.243 .781,0$ & 73,44 & $269.692,3$ & 15,9 & $1.693 .781,5$ \\
\hline 2015 & $189.270,8$ & 9,90 & $1.286,056,6$ & 67,25 & $437.076,1$ & 22,9 & $1.912 .403,4$ \\
\hline 2016 & $194.370,2$ & 9,94 & $1.372 .431,5$ & 70,15 & $467.261,2$ & 23,9 & 1.956 .475 .3 \\
\hline Jumlah & $\mathbf{7 4 9 . 2 0 6 , 0}$ & $\mathbf{4 4 , 1}$ & $\mathbf{6 . 0 5 3 . 5 6 3 , 4}$ & $\mathbf{3 6 9 , 7}$ & $\mathbf{1 . 4 0 3 . 0 7 8 , 6}$ & $\mathbf{7 8 , 9}$ & $\mathbf{8 . 2 7 3 . 3 7 6 , 7}$ \\
\hline Rerata & $\mathbf{1 4 9 . 8 4 1 , 2}$ & $\mathbf{8 , 8 2}$ & $\mathbf{1 . 2 0 1 . 7 1 2 , 7}$ & $\mathbf{7 3 , 9 0}$ & $\mathbf{2 8 0 . 6 1 8 , 8}$ & $\mathbf{1 5 , 8}$ & $\mathbf{1 . 6 5 4 . 6 7 5 , 4}$ \\
\hline
\end{tabular}

Sumber: Kabupaten Lombok Timur Dalam Angka Tahun 2012-2016, diolah.

Dari tabel di atas dapat ditunjukkan sumber-sumber pendapatan daerah baik yang berasal dari pendapatan asli daerah (PAD), dana perimbangan dan pendapatan lain yang syah selama 5 (lima) tahun terhitung sejak tahun 2012-2016. Selanjutnya dari tabel tersebut dapat dilihat proporsi masing-masing sumber pendapatan terhadap total pendapatan daerah setiap tahunnya. Sebagai ilustrasi proporsi PAD terhadap total pendapatan tahun 2012 sebesar 6,9 persen, pada tahun 2016 menurun menjadi 9,94 persen atau rata-rata proporsi PAD terhadap total pendapatan daerah selama lima tahun sebesar 8,82 persen. Proporsi dana perimbangan terhadap total pendapatan daerah selama lima tahun terakhir mengalami fluktuasi. Pada tahun 2012 proporsinya sebesar 80,08 persen dan terus mengalami penurunan sampai tahun 2015 menjadi 67,25 persen, namun pada tahun 2015 terjadi kenaikan menjadi 70,15 persen. Atau rata-rata proporsi dana perimbangan terhadap total pendapatan daerah sejak tahun 2012-2016 sebesar 73,90 persen. Sedangkan proporsi pendapatan lain yang syah terhadap total pendapatan daerah juga mengalami fluktuasi. Sejak tahun tahun 2012 proporsi pendapatan lain yang syah terhadap total pendapatan daerah sebesar 1,66 persen kemudian mengalami peningkatan sampai tahun 2016 proporsinya menjadi 23,9 persen. Atau secara rata-rata selama lima tahun terakhir sejak tahun 2012-2016 proporsinya sebesar 15,8 persen.

Peningkatan penerimaan pendapatan daerah yang relatif kecil terutama yang bersumber dari PAD membawa konsekuensi terhadap peningkatan dana perimbangan yang relatif cukup besar guna memenuhi belanja daerah yang semakin meningkat. Hal ini juga disebabkan oleh belum signifikannya peningkatan sumber penerimaan daerah yang berasal dari sumber penerimaan lain yang syah sejak tahun 2012-2016. Dari kondisi tersebut di atas dapat dikatakan bahwa sumber-sumber pendapatan daerah tidak diikuti dengan perkembangan pencapaian realisasi belanja daerah secara proforsional sebagaimana dapat dilihat pada tabel berikut ini : 
Tabel 1.2. Realisasi Belanja Aparatur, Belanja Pelayanan Publik, Belanja Bagi Hasil dan Belanja Tak Terduga Kabupaten Lombok Timur tahun 2012-2016 (jutaan rupiah)

\begin{tabular}{|c|c|c|c|c|c|c|c|c|c|}
\hline Tahun & $\begin{array}{c}\text { Belanja } \\
\text { Operasi }\end{array}$ & $\mathbf{\%}$ & $\begin{array}{c}\text { Belanja } \\
\text { Modal }\end{array}$ & $\begin{array}{c}\text { Belanja } \\
\text { Tak } \\
\text { Terduga }\end{array}$ & $\begin{array}{c}\text { \% } \\
\text { Transfer }\end{array}$ & \% & $\begin{array}{c}\text { Total } \\
\text { Belanja }\end{array}$ \\
\hline 1 & 2 & $3=2: 10$ & 4 & $5=4: 1$ & 6 & $\begin{array}{c}7=6: 1 \\
0\end{array}$ & 8 & $9=8: 10$ & 10 \\
\hline 2012 & $1.040 .590,7$ & 86,07 & $274.779,5$ & 22,73 & $4.000,0$ & 0,33 & $\begin{array}{l}1.377 .845 \\
, 1\end{array}$ & 113,96 & $1.209 .073,9$ \\
\hline 2013 & $1.290 .079,7$ & 95.08 & $291.413,7$ & 21,48 & $9.000,0$ & 0,67 & $\begin{array}{l}1.590 .493 \\
, 4\end{array}$ & 117,22 & $1.356 .878,4$ \\
\hline 2014 & $1.024 .984,1$ & 63,11 & $20.744,5$ & 1,28 & $12.500,0$ & 0,77 & $\begin{array}{l}1.807 .801 \\
, 1\end{array}$ & 111,30 & $1.624 .283,5$ \\
\hline 2015 & $1.189 .984,5$ & 71,72 & $226.997,9$ & 13,68 & $3.745,4$ & 0,23 & $\begin{array}{l}1.926 .783 \\
, 4\end{array}$ & 116,12 & $1.659 .300,3$ \\
\hline 2016 & $1.273 .429,2$ & 78,18 & $447.396,5$ & 27,47 & $8.000,0$ & 0,50 & $\begin{array}{l}1.982 .058 \\
, 6\end{array}$ & 121,69 & $1.628 .825,0$ \\
\hline $\begin{array}{l}\text { Jumla } \\
\text { h }\end{array}$ & & $\mathbf{3 9 4 , 2}$ & & $\mathbf{8 6 , 6 4}$ & & $\mathbf{2 , 5}$ & & $\mathbf{5 8 0 , 2 3}$ & \\
\hline Rerata & & $\mathbf{7 8 , 8 3}$ & & $\mathbf{1 7 , 3 2}$ & & $\mathbf{0 , 5 0}$ & & $\mathbf{1 1 6 , 0 5}$ & \\
\hline
\end{tabular}

Sumber: Kabupaten Lombok Timur Dalam Angka Tahun 2012-2016, diolah.

Bersumber dari tabel di atas dapat ditunjukkan bahwa proporsi belanja operasi terhadap total belanja daerah pada tahun 2012 sebesar 86,07 persen, pada tahun 2014 menurun menjadi 63,11, namun tahun berikutnya (2015) naik lagi menjadi 71,72 persen sampai dengan tahun 2016 mengalami kenaikan menjadi 78,18 persen atau secara rata-rata proporsi belanja operasi terhadap total belanja daerah selama lima tahun sebesar 78,83 persen. Proporsi belanja modal terhadap total belanja daerah selama lima tahun terakhir terus berfluktuasi. Pada tahun 2012 proporsi belanja modal terhadap total belanja daerah sebesar 22,73 persen. Pada tahun 2014 terjadi penurunan yang sangat drastis hanya 1,28 persen. Dilihat secara rata-rata proporsi dana belanja modal terhadap total belanja daerah sejak tahun 2012-2016 sebesar 17,32 persen.

Sedangkan proporsi belanja Tak Terduga terhadap total belanja daerah juga mengalami fluktuasi juga. Sejak tahun tahun 2012 proporsi belanja Tak Terduga terhadap total belanja daerah sebesar 0,33 persen, proporsi tertinggi terjadi pada tahun 2014 sebesar 0,77 persen, kemudian mengalami penurunan sampai tahun 2016 proporsi belanja Tak Terduga terhadap total belanja daerah menjadi 0,5 persen. Atau secara rata-rata selama lima tahun terakhir sejak tahun 2012-2016 proporsi belanja Tak Terduga terhadap belanja daerah sebesar 0,50 persen. Selanjutnya proporsi belanja Transfer selama lima tahun terhitung sejak tahun 2012-2016 juga mengalami peningkatan secara terus menerus. Sebagai ilustrasi Tahun 2012 proporsi belanja Transfer terhadap total belanja daerah sebesar 113,96 persen, terus mengalami peningkatan sampai tahun 2016 telah menjadi 121,69 persen. Jika dilihat secara rata-rata proporsi belanja Transfer terhadap total belanja daerah sebesar 116,05 persen.

\subsection{Perumusan Masalah}

1. Bagaimana dampak pengalokasian dana perimbangan terhadap laju percepatan pertumbuhan ekonomi Kabupaten Lombok Timur terhitung sejak Tahun 2012-2016.

2. Berapa besar kontribusi dana perimbangan dalam mendorong laju percepatan pertumbuhan ekonomi Kabupaten Lombok Timur terhitung sejak Tahun 2012-2016. 


\subsection{Tujuan Penelitian}

Adapun tujuan utama yang ingin diamati dalam penelitian ini adalah untuk :

1. Menganalisis bagaimana dampak pengalokasian dana perimbangan terhadap laju percepatan pertumbuhan ekonomi Kabupaten Lombok Timur terhitung sejak Tahun 2012-2016.

2. Menganalisis kontribusi dana perimbangan terhadap laju percepatan daya dorong pertumbuhan ekonomi Kabupaten Lombok Timur terhitung sejak Tahun 2012-2016.

\subsection{Hal-hal yang Akan Dianalisis}

Adapun variabel-variabel yang akan dianalisis dalam penelitian ini meliputi beberapa hal antara lain : Pendapatan Daerah, Pendapatan Asli Daerah, Dana Perimbangan, Pendapatan lain Yang Syah, Belanja Aparatur, Belanja Pelayanan Publik dan Belanja Bagi Hasil

\section{TINJAUAN PUSTAKA}

\subsection{Hasil Penelitian Terdahulu}

Dalam penelitian yang dilakukan oleh Hasbullah (2006 : 9) yang berjudul Analisis Kemampuan Keuangan Daerah Kota Mataram. Adapun variabel-variabel yang diamati dalam penelitian tersebut meliputi : Pendapatan Daerah, Belanja Daerah, Total Pendapatan Daerah (TPD), Bagi Hasil Pendapatan Bukan Pajak (BHPBP), APBD dan PDRB. Dari hasil kajiannya disimpulkan bahwa proporsi PAD terhadap Total Pendapatan Daerah (TPD) sebesar 7,87 persen, proporsi PAD ditambah BHPBP terhadap TPD sebesar 20,68 persen, rasio PAD terhadap belanja aparatur sebesar 14,16 persen, rasio PAD ditambah BHPBP terhadap belanja aparatur sebesar 37,19 persen. Akan tetapi jika diamati perkembangannya dari tahun ke tahun nampak bahwa proporsi PAD ini semakin menurun. Kondisi ini menunjukkan bahwa ketergantungan pemerintah daerah terhadap pemerintah pusat semakin besar. Ketergantungan yang semakin besar ini antara lain disebabkan oleh kondisi umum yang terjadi di semua kabupaten/kota yang diakibatkan oleh perubahan struktur anggaran seperti : gaji guru SD yang masuk dalam APBD, kenaikan gaji Pegawai Negeri Sipil (PNS). Keadaan ini akan mengakibatkan bertambahnya total APBD yang sumber penerimaannya berasal dari dana sumbangan pemerintah pusat.

Dalam penelitiannya yang lain Hasbullah (2006 : 6) yang berjudul Analisis Rasio Keuangan Pada Anggaran Pendapatan dan Belanja Daerah Kabupaten Lombok Barat. Dimana variabel-variabel yang diamati dalam penelitian tersebut meliputi : Pendapatan Daerah, Belanja Aparatur Daerah, Belanja Pelayanan Publik, Biaya Pungutan PAD, Target Penerimaan PAD dan APBD. Dikatakan bahwa rasio kemandirian menggambarkan ketergantungan pemerintah daerah terhadap sumber dana dari luar (ekstern). Semakin tinggi rasio kemandirian mengandung arti bahwa tingkat ketergantungan pemerintah daerah terhadap bantuan pihak luar/ekstern (terutama pemerintah pusat/provinsi) semakin rendah, dan demikian pula sebaliknya. Rasio kemandirian juga menggambarkan tingkat partisipasi masyarakat dalam pembangunan daerah. Semakin tinggi rasio kemandirian, semakin tinggi pula partispasi masyarakat dalam membayar pajak dan retribusi daerah yang merupakan komponen utama pendapatan asli daerah (PAD). Semakin tinggi masyarakat membayar pajak dan retrebusi daerah akan dapat menggambarkan tingkat kesejahtraan masyarakat yang semakin tinggi pula. Berdasarkan hasil kajiannya sejak Tahun Anggaran 2002 - 2005 disimpulkan bahwa besarnya rasio kemandirian keuangan kabupaten Lombok Barat sebesar 8,70 persen, 6,65 persen, 8,34 persen dan 8,09 persen. Ini 
berarti kemandirian daerah Kabupaten Lombok Barat dalam mencukupi kebutuhan pembiayaan untuk melakukan tugas pemerintahan, pembangunan dan pelayanan masyarakat relatif masih rendah bahkan cendrung menurun.

\subsection{Landasan Teori}

\subsubsection{Kinerja Keuangan Daerah}

Menurut Nizarwan dalam Halim (2004 : 70) dalam bukunya yang berjudul Bunga Rampai Manajemen Keuangan Daerah mengatakan Kebijakan umum pengelolaan keuangan daerah disesuaikan dengan situasi dan kondisi serta potensi daerah dengan berpedoman pada Undang-undang Nomor : 32 Tahun 2004 dan Undang-undang Nomor : 33 tahun 2004. Kesimpulannya adalah Kebijakan pengelolaan keuangan daerah dalam mengalokasikan belanja aparatur dan belanja pelayanan publik senantiasa berpegang pada prinsip anggaran berimbang dan dinamis serta efisien dan efektif dalam meningkatkan produktivitas. Menurut Mardiasmo (2004) dalam bukunya yang berjudul Otonomi dan Manajemen Keuangan Daerah mengatakan Anggaran merupakan pernyataan mengenai estimasi kinerja yang hendak dicapai selama priode waktu tertentu yang dinyatakan dalamukuran finansial dan berisi rencana kegiatan yang direpresentasikan dalam bentuk rencana perolehan pendapatan dan belanja dalam satuan moneter.

Menurut Indra Bastian (2001 : 6) dalam bukunya yang berjudul Manual Akuntansi Keuangan Pemerintah Daerah mengatakan bahwa penyusunan APBD adalah suatu hal yang sangat penting dalam rangka penyelenggaraan fungsi daerah otonom yang bertujuan untuk : menentukan jumlah pajak yang akan dibebankan kepada masyarakat, suatu sarana untuk mewujudkan otonomi yang nyata dan bertanggung jawab, memberi isi dan arti dari pemerintah pusat ke pemerintah daerah, sarana untuk pengawasan dan pemberian kuasa kepala daerah untuk penyelenggaraan keuangan daerah.

\subsubsection{Pengelolaan Keuangan Daerah}

Dalam Peraturan Pemerintah Nomor 58 Tahun 2005 pengganti Peraturan Pemerintah Nomor 105 Tahun 2000 memberikan definisi Pengelolaan Keuangan Daerah adalah keseluruhan kegiatan yang meliputi perencanaan, pelaksanaan, penatausahaan, pelaporan, pertanggungjawaban, dan pengawasan keuangan daerah sedangkan Undang-undang Nomor 17 Tahun 2003 tentang Keuangan Negara bahwa pendapatan daerah dan belanja daerah yang merupakan bagian dari keuangan negara harus dikelola secara tertib, taat pada peraturan perundang-undangan, efisien, ekonomis, efektif, transparan, dan bertanggungjawab dengan memperhatikan rasa keadilan dan kepatuhan.

Menurut Jaya dalam Munir, Djuanda, Tangkilisan (2004: 6) Keuangan Daerah adalah seluruh tatanan, perangkat kelembagaan dan kebijaksanaan anggaran daerah yang meliputi pendapatan dan belanja daerah, sedangkan menurut Peraturan Pemerintah Nomor 105 Tahun 2000 menjelaskan Keuangan Daerah adalah semua hak dan kewajiban daerah dalam rangka penyelenggaraan pemerintahan daerah yang dapat dinilai dengan uang termasuk didalamnya segala bentuk kekayaan yang berhubungan dengan hak dan kewajiban daerah tersebut, dalam kerangka Anggaran Pendapatan dan Belanja Daerah (APBD). Menurut Bastian (2001:8) adanya hubungan yang erat antara Keuangan Negara dan Keuangan Daerah yang merupakan dasar pengelolaan keuangan daerah. Sehingga baik dalam penyusunan APBD dan pelaporan keuangan daerah maupun pelaksanaannya, menceminkan pelaksanaan otonomi daerah yang nyata dan bertanggungjawab yang mencakup hal - hal sebagai berikut (1) Harus serasi dengan pembinaan politik dan kesatuan bangsa; (2) Harus dapat menjamin hubungan yang serasi antara pemerintah pusat dan pemerintah daerah atas dasar keutuhan negara kesatuan; (3) Harus dapat menjamin 
perkembangan dan pembangunan daerah termasuk prinsip - prinsip pembagian sumber sumber keuangan yang adil; (4) Mampu memberdayakan dan meningkatkan kemampua perekonomian daerah; (5) Dapat menciptakan sistem pembiayaan daerah yang adil, proporsional, rasional, transparan, partisipatif, bertanggungjawab (akuntabel) dan pasti; dan (6) Semakin mempertegas sistem pertanggungjawaban keuangan oleh Pemerintah Daerah.

Menurut Devas et al dikutip dalam Munir, Djuanda, Tangkilisan (2004: 7) pengelolaan keuangan daerah berarti mengurus dan mengatur keuangan daerah itu sendiri berdasarkan pada prinsip-prinsip : (1) tanggung jawab, (2) mampu memenuhi kewajiban keuangan, (3) kejujuran, (4) hasil guna dan daya guna, dan (5) pengendalian. Melalui misi utama dan tujuan utama pengelolaan keuangan daerah di atas, terlihat bahwa pemerintah daerah harus mempertanggung jawabkan tugas keuangannya kepada lembaga atau orang yang berkepentingan yang sah, yang meliputi DPRD dan masyarakat. Selain itu efektivitas dan efisiensi dalam pengelolaan keuangan daerah juga harus dilaksanakan. Hal ini berarti dalam pengelolaan keuangan daerah harus dilaksanakan sedemikian rupa sehingga program dan kegiatan yang telah direncanakan dapat dilaksanakan untuk mencapai tujuan pemerintah daerah dengan biaya yang serendah-rendahnya dan dalam waktu yang secepatcepatnya. Secara garis besar, manajemen keuangan daerah dapat dibagi menjadi dua bagian, yaitu manajemen penerimaan daerah dan manajemen pengeluaran daerah. Kedua komponen tersebut akan sangat menentukan kedudukan suatu pemerintah daerah dalam rangka melaksanakan otonomi daerah (Mardiasmo, 2002).

\subsubsection{Anggaran Pendapatan dan Belanja Daerah (APBD)}

Sesuai Peraturan Pemerintah Nomor 105 Tahun 2000 tentang Pengelolaan dan pertanggungjawaban Keuangan Daerah, APBD adalah suatu rencana keuangan tahunan daerah yang ditetapkan berdasarkan Peraturan Daerah tentang APBD. Dengan demikian, pemungutan semua penerimaan daerah dalam rangka pelaksanaan desentralisasi bertujuan untuk memenuhi target yang ditetapkan dalam APBD. Semua pengeluaran daerah dan ikatan yang membebani daerah dalam rangka pelaksanaan desentralisasi dilakukan sesuai jumlah dan sasaran yang ditetapkan dalam APBD, sehingga APBD menjadi dasar bagi kegiatan pengendalian, pemeriksaan dan pengawasan keuangan daerah. APBD merupakan dasar pengelolaan keuangan daerah dalam tahun anggaran tertentu.

Menurut UU Nomor 32 Tahun 2004 tentang Pemerintahan Daerah sumber penerimaan daerah terdiri dari (1) Pendapatan Asli Daerah (PAD), (2) Dana Perimbangan dan (3) Lain-lain pendapatan daerah yang syah. Sedangkan menurut UU Nomor 33 Tahun 2004 tentang Perimbangan Keuangan Antara Pemerintah Pusat dan Pemerintah Daerah dalam pasal 5 ayat (1) menyatakan bahwa penerimaan daerah dalam pelaksanaan desentralisasi terdiri atas pendapatan daerah dan pembiayaan. Selanjutnya ayat 2 menjelaskan bahwa pendapatan daerah sebagaimana dimaksud pada ayat 1 bersumber dari : (1) Pendapatan Asli Daerah (PAD), (2) Dana Perimbangan dan (3) Lain-lain pendapatan.

Menurut Surat Edaran Menteri Dalam Negeri RI Nomor 903/2477/SJ tanggal 5 Desember 2001 perihal Pedoman Umum Penyusunan dan Pelaksanaan APBD Tahun Anggaran 2002, bahwa penyusunan APBD harus mengacu pada norma dan prinsip anggaran sebagai berikut:

\section{Transparansi dan Akuntabilitas Anggaran}

Merupakan persyaratan utama untuk mewujudkan pemerintahan yang baik, bersih dan bertanggungjawab. Sebagai instrument evaluasi pencapaian kinerja dan tanggungjawab Pemerintah Daerah mensejahterakan masyarakat, maka APBD harus dapat menyajikan 
informasi yang jelas tentang tujuan, sasaran, hasil dan manfaat yang diperoleh masyarakat dari suatu kegiatan atau proyek yang dianggarkan yang meliputi :

\section{a. Disiplin Anggaran}

APBD harus disusun berorientasi pada kebutuhan masyarakat tanpa harus meninggalkan keseimbangan antara pembiayaan penyelenggaraan pemerintahan, pembangunan dan pelayanan masyarakat. Oleh karena itu penyusunan anggaran hendaknya dilakukan berlandaskan azas efisiensi, tepat guna, tepat waktu pelaksanaan dan penggunaannya dapat dipertanggungjawabkan.

\section{b. Keadilan Anggaran}

Pendapatan Daerah pada hakekatnya diperoleh melalui mekanisme pajak dan retribusi atau beban lainnya yang dipikul oleh segenap lapisan masyarakat. Untuk itu, Pemerintah Daerah wajib mengalokasikan pengunaannya secara adil dan merata agar dapat dinikmati oleh seluruh kelompok masyarakat tanpa diskriminasi dalam pemberian pelayanan.

Menurut Mardiasmo (2004) anggaran merupakan pernyataan mengenai estimasi kinerja yang hendak dicapai selama periode waktu tertentu yang dinyatakan dalam ukuran finansial dan berisi rencana kegiatan yang direpresentasikan dalam bentuk rencana perolehan pendapatan dan belanja dalam satuan moneter. Anggaran sektor publik merupakan instrumen akuntabilitas atas pengelolaan dana publik dan pelaksanaan program - program yang dibiayai dengan uang publik. Penganggaran sektor publik terkait dengan proses penentuan jumlah alokasi dana untuk tiap - tiap program dan aktifitas dalam satuan moneter.

\subsubsection{Perhitungan Anggaran}

Secara ringkas susunan perhitungan APBD dapat dilihat pada contoh berikut :

1. Jumlah Penerimaan dan Pengeluaran perhitungan APBD tahun anggaran 200x sebagai berikut :

a. Perhitungan Anggaran Pendapatan..................... Rp. Xxxx

b. Perhitungan Anggaran Belanja :

- Aparatur .......................Rp. $x x x x$

- Pelayanan Publik .............. Rp. xxxx

Jumlah Belanja ......................................

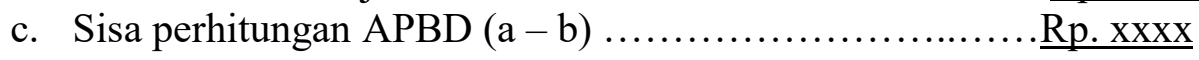

2. Jumlah Penerimaan dan pengeluaran UKP tahun anggaran 200x adalah sebagai berikut :

a. Perhitungan anggaran Pendapatan ...................... $\mathrm{xxxx}$

b. Perhitungan anggaran Belanja :

- Aparatur ......................Rp. xxxx

- Pelayanan Publik ..............Rp. xxxx

Jumlah Belanja ..................................... xxxx

c. Sisa perhitungan UKP ............................... Np. Nihil

Dari gambaran di atas, maka dapat diketahui bahwa unsur utama perhitungan anggaran daerah (APBD) adalah penetapan sisa perhitungan tersebut merupakan penghubung antara APBD tahun anggaran yang lalu dengan APBD tahun anggaran berikutnya. Hal ini terlihat pada saat berakhirnya tahun anggaran (31 Desember) dan pada saat dimulainya APBD tahun anggaran yang baru (1 Januari), di mana sebelum terjadi aktivitas Pendapatan Daerah, di dalam kas daerah telah tersedia uang kas/ tunai yang secara langsung merupakan bagian dari sisa perhitungan anggaran tahun yang lalu. Sisa 
perhitungan anggaran tersebut dimasukkan dalam APBD serta perhitungan APBD sebagai sumber penerimaan pada tahun anggaran berikutnya.

\section{Kerangka Konseptual}

\section{Gambar 1 : Bagan Kerangka Pikir Penelitian}

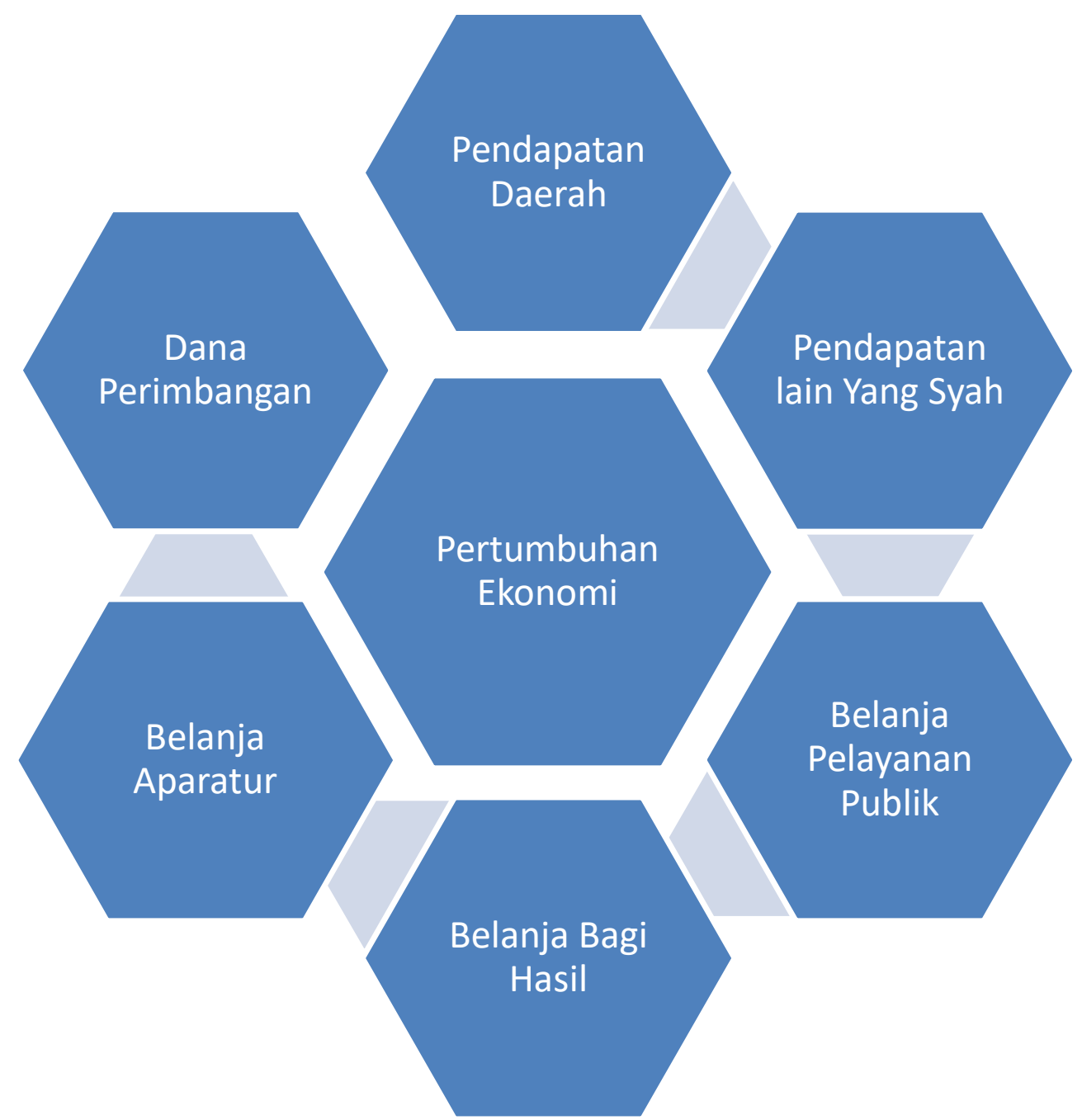

\subsection{Jenis Penelitian}

\section{METODE PENELITIAN}

Penelitian ini termasuk penelitian deskriptif, yang dilakukan untuk mengetahui nilai variabel mandiri, baik satu variabel atau lebih (independent) tanpa membuat perbandingan atau menghubungkan dengan variabel yang lain (Sugiyono, 1999:11). Selanjutnya menurut Kuncoro (2003:8) Penelitian deskriptif meliputi pengumpulan data untuk diuji hipotesis atau menjawab pertanyaan mengenai status terakhir dari subjek penelitian. Penelitian deskriptif berupaya untuk memperoleh deskripsi yang lengkap dan akurat dari suatu situasi.

\subsection{Lokasi Penelitian}

Penelitian ini dilaksanakan di Kabupaten Lombok Timur Provinsi Nusa Tenggara Barat, dipilihnya Kabupaten Lombok Timur secara purposive sampling dengan dasar 
pertimbangan bahwa Kabupaten Lombok Timur merupakan salah satu daerah Kabupaten di Provinsi Nusa Tenggara Barat yang paling banyak dan terpadat jumlah penduduknya jika dibandingkan dengan kabupaten lain di Provinsi Nusa Tenggara Barat. Diharapkan dengan terpilihnya Kabupaten Lombok Timur sebagai lokasi penelitian akan memberikan berbagai kemudahan dari berbagai akses seperti data dan informasi lainnya.

\subsection{Teknik dan Alat Pengumpulan Data}

Data yang berkaitan dengan analisis dana perimbangan dilakukan dengan cara :

1. Studi kepustakaan (Library Research), yaitu dengan cara mempelajari buku-buku, karangan ilmiah, jurnal ilmiah serta dokumen-dokumen lain yang berkaitan dengan analisis pertumbuhan ekonomi sesuai dengan judul penelitian.

2. Penelitian lapangan (Field Research), yaitu melakukan pengamatan secara langsung di lapangan terutama pada Biro Keuangan Sekretariat Daerah Kabupaten Lombok Timur Provinsi NTB sehubungan dengan data-data dan informasi terkait dengan variabelvariabel penelitian di atas.

\subsection{Jenis dan Sumber Data}

Penelitian ini menggunakan data skunder yaitu data yang sudah dikumpulkan langsung dari Biro sekretariat Daerah Kabupaten Lombok Timur sesuai data yang diperlukan dalam penelitian. Adapun data yang dimaksudkan terdiri dari : data APBD, Perubahan APBD, laporan perhitungan APBD, realisasi penerimaan daerah, realisasi belanja daerah, Nota Perhitungan APBD, Arus Kas dan Buku Perhitungan APBD, data PDRB, data demografis, perkembangan APBD, penerimaan dan belanja daerah, dan mekanisme penganggaran serta data-data Kabupaten Lombok Timur lainnya yang mendukung judul penelitian Kabupaten Lombok Timur Provinsi NTB Tahun Anggaran 2012-2016.

\subsection{Identifikasi dan Klasifikasi Variabel}

Dalam penelitian ini variabel yang diidentifikasi adalah sebagai berikut:

1.Pendapatan Daerah

2.Pendapatan Asli Daerah

3. Dana Perimbangan

4. Pendapatan lain Yang Syah

5. Belanja Aparatur

6. Belanja Bagi Hasil

7. Belanja Pelayanan Publik

8. Produk Domestik Regional Brutto (PDRB)

\subsection{Definisi Operasional Variabel}

Untuk menghindari penafsiran yang berbeda terhadap beberapa variabel yang digunakan dalam penelitian ini maka diberikan batasan-batasan sebagai berikut :

1. Pendapatan Daerah (PD) adalah semua penerimaan kas daerah dalam periode tahun anggaran tertentu yang menjadi hak daerah, tidak termasuk didalamnya unsur penerimaan UKP dalam kurun waktu tertentu (satu tahun)

2. Dana Perimbangan adalah dana yang diberikan oleh pemeerintah pusat yang terdiri dari dana alokasi umum (DAU) dan dana alokasi khusus (DAK) yang disesuaikan besarnya masing-masing daerah berbeda.

3. Pendapatan lain Yang Syah adalah pendapatan daerah yang berasal dari berbagai sumber diantaranya bisa berasal dari deviden dalam penyertaan modal daerah, hibah baik yang berasal dari pemerintah pusat maupun dari pihak luar. 
4. Belanja Aparatur adalah semua pengeluaran kas daerah yang dipergunakan untuk mendanai administrasi penyelenggaraan pemerintahan daerah seperti : gaji Pegawai Negeri Sipil (PNS), Vakasi, lembur, pengadaan sarana dan parasarana birokrasi serta fasilitas lainnya termasuk pemeliharaan fasilitas inventaris yang sekaligus akan menjadi beban daerah dalam kurun waktu tertentu (satu tahun).

5. Belanja Pelayanan Publik adalah semua pengeluaran kas daerah yang dipergunakan untuk mendanai seluruh aktivitas pelayan publik seperti : pembangunan sarana pendidikan, sarana kesehatan, sarana perhubungan dan fasilitas umum lainnya yang dibutuhkan masyarakat sekaligus akan menjadi beban daerah dalam kurun waktu tertentu (satu tahun).

6. Belanja Bagi Hasil adalah dana yang dialokasikan dari anggaran pendapatan belanja daerah (APBD) untuk keperluan penyertaan modal daerah dalam perusahaan daerah.

7. Belanja Daerah adalah adalah semua pengeluaran kas daerah dalam periode tahun anggaran tertentu yang menjadi beban daerah, terdiri dari belanja aparatur dan belanja pelayanan publik.

8. Produk Domestik Regional Brutto (PDRB) adalah seluruh nilai produk barang dan jasa yang diproduksi di wilayah Kabupaten Lombok Timur tanpa memperhatikan apakah faktor produksinya berasal dari/atau dimiliki oleh penduduk Kabupaten Lombok Timur selama jangka waktu tertentu (satu tahun).

\subsection{Model Analisis Data}

\section{- Rasio Kemandirian dan Kinerja Keuangan Daerah}

Kemandirian dan kinerja keuangan daerah menunjukkan kemampuan daerah dalam membiayai dirinya sendiri dalam pelaksanaan kegiatan administrasi pemerintahan, pembangunan dan pelayanan kepada masyarakat (publik) yang telah membayar pajak, retrebusi, hasil pengelolan kekayaan daerah serta lain-lain PAD yang syah. Kemandirian dan kinerja keuangan daerah dimaksud dapat ditunjukkan melalui ratio beberapa indikator seperti : Rasio PAD Terhadap Pendapatan Daerah, Rasio Dana Perimbangan Terhadap Pendapatan Daerah, Rasio Pendapatan lain Yang Syah Terhadap Pendapatan Daerah, Rasio Belanja Aparatur Terhadap Pendapatan Daerah, Rasio Belanja Bagi Hasil Terhadap Pendapatan Daerah, Rasio Belanja Pelayanan Publik Terhadap Pendapatan Daerah, Rasio Produk Domestik Regional Brutto Terhadap Pendapatan Daerah

\section{HASIL DAN PEMBAHASAN}

\subsection{Perkembangan Kondisi Keuangan Daerah}

Realisasi pendapatan daerah Kabupaten Lombok Timur tahun 2016 sebesar 2,22 Trilyun Rupiah meningkat sekitar 200 milyar rupiah atau 12,9 persen dibandingkan dengan realisasi di tahun 2015. Dilihat dari komposisinya sebagian besar pendapatan ini bersumber dari berasal dari Dana alokasi Umum (DAU). Pada tahun 2016 DAU yang diterima sebesar 1,16 Trilyun atau sekitar 52,29 persen dari total pendapatan daerah. Sedangkan pendapatan yang berasal dari Pendapatan Asli Daerah (PAD) tidak terlalu besar dilihat dari persentasinya terhadap total pendapatan. Tahun 2016 PAD Kabupaten Lombok Timur berjumlah 236 milyar atau sekitar 10,62 persen saja. Meskipun demikian jumlah PAD dari tahun ke tahun terus mengalami peningkatan. Jika dilihat dari segi penggunaan 
atau belanja daerah, total belanja daerah mencapai 2,23 trilyun pada tahun 2016. Lebih besar dibandingkan dengan belanja tahun 2015 yang mencapai 1,66 trilyun. Dari komponen belanja daerah tersebut, belanja pegawai ternyata merupakan komponen yang paling besar. Sebagai ilustrasi jumlah belanja pegawai pada tahun 2016 mencapai 1,09 trilyun atau sekitar 48,89 persen dari total belanja daerah.

Jika dilihat kondisi pendapatan daerah Kabupaten Lombok Timur tahun 2015 sebesar 1,91 Trilyun rupiah terjadi peningkatan sekitar 218,6 milyar rupiah atau sebesar 12,9 persen jika dibandingkan dengan realisasi pada tahun 2014. Jika dilihat dari segi kompisisnya sebahagian besar pendapatan ini berasal dari Dana Alokasi Umum (DAU). Pada tahun 2015 jumlah DAU yang diterima mencapai 1,08 Trilyun atau sekitar 56,5 persen dari total pendapatan daerah. Sedangkan pendapatan yang bersumber dari Pendapatan Asli Daerah (PAD) tidak terlalu besar dilihat dari segi persentasinya terhadap total pendapatan. Sebagai ilustrasi pada tahun 2015 PAD Kabupaten Lombok Timur sejumlah 189,27 molyar atau sekitar 9,9 persen dari total pendapatan daerah. Mekipun demikian jumlah PAD Kabupaten Lombok Timur dari tahun ke tahun menunjukkan angka peningkatan. Jika dilihat dari segi penggunaan atau belanja daerah, total belanja daerah mencapai 1,66 trilyun pada tahun 2015. Lebih besar dibandingkan dengan belanja tahun 2014 yang mencapai 1,62 trilyun. Dari komponen belanja daerah tersebut, belanja pegawai ternyata merupakan komponen yang paling besar. Sebagai ilustrasi jumlah belanja pegawai pada tahun 2015 mencapai 1,02 trilyun atau sekitar 61,35 persen dari total belanja daerah.

Selanjutnya secara lebih komprehensif untuk melihat laju pertumbuhan Pendapatan Daerah Kabupaten Lombok Timur sejak tahun 2012-2016 akan disajikan pada tabel di bawah :

Tabel : IV. 1. Pendapatan Daerah Kabupaten Lombok Timur Tahun 2012-2016 (jutaan rupiah)

\begin{tabular}{|c|c|c|c|}
\hline Tahun & $\begin{array}{c}\text { Target } \\
\text { Anggaran }\end{array}$ & $\begin{array}{c}\text { Realisasi } \\
\text { Anggaran }\end{array}$ & $\begin{array}{c}\text { Pertumbuhannya } \\
(\mathbf{\%})\end{array}$ \\
\hline 2012 & 1.395 .026 & 1.276 .066 & 9,46 \\
\hline 2013 & 1.666 .585 & 1.404 .903 & 10,03 \\
\hline 2014 & 1.821 .334 & 1.693 .781 & 20,58 \\
\hline 2015 & 1.912 .404 & 2.007 .874 & 18,54 \\
\hline 2016 & 2.223 .806 & 2.239 .840 & 11,55 \\
\hline J u m I a h & $\mathbf{9 . 0 1 9 . 1 5 5}$ & $\mathbf{8 . 6 2 2 . 4 6 4}$ & $\mathbf{7 0 , 1 6}$ \\
\hline Rata-rata & $\mathbf{1 . 8 0 3 . 8 3 1}$ & $\mathbf{1 . 7 2 4 . 4 9 2}$ & $\mathbf{1 4 , 0 3}$ \\
\hline
\end{tabular}

Sumber : Kabupaten Lombok Timur dalam Angka 2012-2016, diolah.

Berdasarkan data tabel di atas dapat dijelaskan bahwa angka pertumbuhan pendapatan daerah dilihat dari realisasi anggaran tahun 2012 sebesar 9,46 persen, tahun 2013 sebesar 10,03 persen, tahun 2014 sebesar 20,58 persen, tahun 2015 sebesar 18,54 persen dan tahun 2016 sebesar 11,55 persen. Angka pertumbuhan tertinggi terjadi pada tahun 2014 yaitu sebesar 20,58 persen. Angka pertumbuhan rata-rata selama 5 (lima) tahun terhitung sejak tahun 2014-2016 mencapai 14,03 persen.

\subsection{Perkembangan Pendapatan Asli Daerah (PAD)}

Penjelasan berikutnya akan disajikan bagaimana pertumbuhan dan perkembangan pendapatan asli daerah Kabupaten Lombok Timur selama 5 (lima) tahun terakhir akan disajikan pada tabel di bawah : 
Tabel : IV.2. Pendapatan Asli Daerah (PAD) Kabupaten Lombok Timur Tahun 2012-2016 (jutaan rupiah)

\begin{tabular}{|c|c|c|c|}
\hline Tahun & $\begin{array}{c}\text { Target } \\
\text { Anggaran }\end{array}$ & $\begin{array}{c}\text { Realisasi } \\
\text { Anggaran }\end{array}$ & $\begin{array}{c}\text { Pertumbuhannya } \\
\mathbf{( \% )}\end{array}$ \\
\hline 2012 & 120.430 & 122.077 & 13,67 \\
\hline 2013 & 185.238 & 167.503 & 37,21 \\
\hline 2014 & 205.518 & 180.308 & 7,78 \\
\hline 2015 & 189.270 & 218.906 & 21,11 \\
\hline 2016 & 225.874 & 236.147 & 8,25 \\
\hline J u m I a h & $\mathbf{8 5 3 . 3 3 0}$ & $\mathbf{7 9 0 . 9 4 1}$ & $\mathbf{8 8 , 0 2}$ \\
\hline Rata-rata & $\mathbf{1 7 0 . 6 6 6}$ & $\mathbf{1 5 8 . 1 8 8}$ & $\mathbf{1 7 , 6 4}$ \\
\hline
\end{tabular}

Sumber : Kabupaten Lombok Timur dalam Angka 2012-2016, diolah.

Berdasarkan data tabel di atas dapat dijelaskan bahwa angka pertumbuhan pendapatan asli daerah (PAD) dilihat dari segi realisasi anggaran terhitung sejak tahun 2012 pertumbuhannya sebesar 13,67 persen, tahun 2013 turun drastis menjadi sebesar 37,21 persen, tahun 2014 meningkat drastis menjadi sebesar 7,78 persen, tahun 2015 turun lagi menjadi sebesar 21,11 persen dan tahun 2016 menurun lagi menjadi sebesar 8,25 persen. Angka pertumbuhan tertinggi terjadi pada tahun 2013 yaitu sebesar 37,31 persen. Angka pertumbuhan rata-rata selama 5 (lima) tahun terhitung sejak tahun 2012-2016 mencapai 17.64 persen.

\subsection{Perkembangan Dana Perimbangan}

Selanjutnya untuk melihat bagaimana realisasi dan pertumbuhan dana perimbangan selama 5 (lima) tahun sejak tahun 2012-2016 akan disajikan pada tabel di bawah ini :

Tabel : IV.3. Dana Perimbangan Daerah Kabupaten Lombok Timur Tahun 2012-2016 (jutaan rupiah)

\begin{tabular}{|c|c|c|c|}
\hline Tahun & $\begin{array}{c}\text { Target } \\
\text { Anggaran }\end{array}$ & $\begin{array}{c}\text { Realisasi } \\
\text { Anggaran }\end{array}$ & $\begin{array}{c}\text { Pertumbuhannya } \\
(\mathbf{\%})\end{array}$ \\
\hline 2012 & 1.021 .260 & 1.066 .767 & 4,40 \\
\hline 2013 & 1.218 .269 & 1.129 .526 & 10,58 \\
\hline 2014 & 1.307 .591 & 1.243 .781 & 10,09 \\
\hline 2015 & 1.243 .781 & 1.335 .017 & 7,40 \\
\hline 2016 & 1.695 .428 & 1.749 .586 & 31,01 \\
\hline J u m I a h & $\mathbf{6 . 5 3 1 . 3 2 9}$ & $\mathbf{6 . 4 7 9 . 6 7 7}$ & $\mathbf{6 3 , 4 8}$ \\
\hline Rata-rata & $\mathbf{1 . 3 0 6 . 2 6 5}$ & $\mathbf{1 . 2 9 5 . 9 3 5}$ & $\mathbf{1 2 , 6 9}$ \\
\hline
\end{tabular}

Sumber : Kabupaten Lombok Timur dalam Angka 2012-2016, diolah.

Berdasarkan data tabel di atas dapat dijelaskan bahwa angka pertumbuhan dana perimbangan yang bersumber dari Dana Alokasi Umum (DAU) dilihat dari segi realisasi anggaran terhitung sejak tahun 2012 pertumbuhannya sebesar 4,40 persen, tahun 2013 menjadi sebesar 10,58 persen, tahun 2014 menjadi sebesar 10,09 persen, tahun 2015 meningkat menjadi sebesar 7,40 persen dan tahun 2016 turun menjadi sebesar 31,01 persen. Angka pertumbuhan tertinggi terjadi pada tahun 2016 yaitu sebesar 31,01 persen. Angka pertumbuhan rata-rata selama 5 (lima) tahun terhitung sejak tahun 2012-2016 mencapai 12,69 persen.

\subsection{Perkembangan Belanja Aparatur}

Selanjutnya untuk melihat bagaimana realisasi dan pertumbuhan Belanja Aparatur selama 5 (lima) tahun sejak tahun 2012-2016 akan disajikan pada tabel di bawah ini : 
Tabel : IV.4. Belanja Aparatur Kabupaten Lombok Timur Tahun 2012-2016 (jutaan rupiah)

\begin{tabular}{|c|c|c|c|}
\hline Tahun & Anggaran & Realisasi & $\begin{array}{c}\text { Pertumbuhannya } \\
(\%)\end{array}$ \\
\hline 2012 & 1.160 .369 & 1.319 .055 & 13,70 \\
\hline 2013 & 1.590 .493 & 1.325 .062 & 14,22 \\
\hline 2014 & 1.807 .801 & 1.624 .283 & 22,56 \\
\hline 2015 & 1.624 .283 & 1.659 .300 & 2,16 \\
\hline 2016 & 2.056 .729 & 2.239 .840 & 34,96 \\
\hline J u m I a h & $\mathbf{8 . 3 9 8 . 6 7 5}$ & $\mathbf{8 . 0 0 8 . 5 4 3}$ & $\mathbf{8 7 , 6 0}$ \\
\hline Rata-rata & $\mathbf{1 . 6 7 9 . 7 3 5}$ & $\mathbf{1 . 6 0 1 . 7 0 8}$ & $\mathbf{1 7 , 5 2}$ \\
\hline
\end{tabular}

Sumber : Kabupaten Lombok Timur dalam Angka 2012-2016, diolah.

Berdasarkan data tabel di atas dapat dijelaskan bahwa angka pertumbuhan Belanja Aparatur dilihat dari segi realisasi anggaran terhitung sejak tahun 2012 pertumbuhannya sebesar 13,70 persen, tahun 2013 menjadi sebesar 14,22 persen, tahun 2014 menjadi sebesar 22,56 persen, tahun 2015 meningkat menjadi sebesar 2,16 persen dan tahun 2016 meningkat menjadi sebesar 34,96 persen. Angka pertumbuhan tertinggi terjadi pada tahun 2016 yaitu sebesar 34,96 persen. Angka pertumbuhan rata-rata selama 5 (lima) tahun terhitung sejak tahun 2012-2016 mencapai 17,52 persen.

\subsection{Perkembangan Belanja Bagi Hasil}

Selanjutnya untuk melihat bagaimana realisasi dan pertumbuhan Belanja Bagi Hasil selama 5 (lima) tahun sejak tahun 2012-2016 akan disajikan pada tabel di bawah ini

Tabel : IV.5. Belanja Bagi Hasil Kabupaten Lombok Timur Tahun 2012-2016 (jutaan rupiah)

\begin{tabular}{|c|c|c|c|}
\hline Tahun & Anggaran & Realisasi & $\begin{array}{c}\text { Pertumbuhannya } \\
(\mathbf{\%})\end{array}$ \\
\hline 2012 & $149.475,00$ & $158.018,61$ & 6,04 \\
\hline 2013 & $195.012,78$ & $210.700,00$ & 33,33 \\
\hline 2014 & $139.538,90$ & $227.093,61$ & $-75,83$ \\
\hline 2015 & $204.500,22$ & $226.997,92$ & $-0,40$ \\
\hline 2016 & $405.279,01$ & $421.798,35$ & 85,81 \\
\hline J u m I a h & $\mathbf{8 0 8 0 . 8 0 5 , 9 1}$ & $\mathbf{6 9 8 . 9 8 2 , 5 2}$ & $\mathbf{4 8 , 9 5}$ \\
\hline Rata-rata & $\mathbf{1 6 1 . 7 6 1 , 1 8}$ & $\mathbf{1 3 9 . 7 9 6 , 5 0}$ & $\mathbf{9 , 7 9}$ \\
\hline
\end{tabular}

Sumber : Kabupaten Lombok Timur dalam Angka 2012-2016, diolah.

Berdasarkan data tabel di atas dapat dijelaskan bahwa angka pertumbuhan Belanja Bagi Hasil dilihat dari segi realisasi anggaran terhitung sejak tahun 2012 pertumbuhannya sebesar 6,04 persen, tahun 2013 menjadi sebesar 33,33 persen, tahun 2014 meningkat menjadi sebesar -75,83 persen, tahun 2015 menjadi sebesar -0,40 persen dan tahun 2016 meningkat menjadi sebesar 85,81 persen. Angka pertumbuhan tertinggi terjadi pada tahun 2016 yaitu sebesar 85,81 persen. Angka pertumbuhan rata-rata selama 5 (lima) tahun terhitung sejak tahun 2012-2016 mencapai 9,79 persen.

\subsection{Perkembangan Belanja Pelayanan Publik}

Selanjutnya untuk melihat bagaimana realisasi dan pertumbuhan Belanja Pelayanan Publik selama 5 (lima) tahun sejak tahun 2012-2016 akan disajikan pada tabel di bawah ini 
Tabel : IV.6. Belanja Pelayanan Publik Kabupaten Lombok Timur Tahun 2012-2016 (jutaan rupiah)

\begin{tabular}{|c|c|c|c|}
\hline Tahun & Anggaran & Realisasi & $\begin{array}{c}\text { Pertumbuhannya } \\
(\mathbf{\%})\end{array}$ \\
\hline 2012 & 185.779 & 274.134 & 48,11 \\
\hline 2013 & 291.413 & 323.322 & 74,59 \\
\hline 2014 & 381.564 & 446.683 & 38,08 \\
\hline 2015 & 446.683 & 469.315 & 5,16 \\
\hline 2016 & 725.428 & 747.566 & 59,27 \\
\hline J u m I a h & $\mathbf{2 . 1 1 9 . 8 6 7}$ & $\mathbf{2 . 1 7 2 . 0 2 0}$ & $\mathbf{2 2 5 , 2 1}$ \\
\hline Rata-rata & $\mathbf{4 2 3 . 9 7 3}$ & $\mathbf{4 3 4 . 4 0 4}$ & $\mathbf{4 5 , 0 4}$ \\
\hline
\end{tabular}

Sumber : Kabupaten Lombok Timur dalam Angka 2012-2016, diolah.

Berdasarkan data tabel di atas dapat dijelaskan bahwa angka pertumbuhan Belanja Pelayanan Publik dilihat dari segi realisasi anggaran terhitung sejak tahun 2012 pertumbuhannya sebesar 48,11 persen, tahun 2013 meningkat menjadi sebesar 74,59 persen, tahun 2014 menjadi sebesar 38,08 persen, tahun 2015 turun menjadi sebesar 5,16 persen dan tahun 2016 meningkat menjadi sebesar 159,27 persen. Angka pertumbuhan tertinggi terjadi pada tahun 2013 yaitu sebesar 74,59 persen. Angka pertumbuhan rata-rata selama 5 (lima) tahun terhitung sejak tahun 2012-2016 mencapai 45,04 persen.

\subsection{Perkembangan Pendapatan Lain Yang Syah}

Selanjutnya untuk melihat bagaimana realisasi dan pertumbuhan Pendapatan Lain Yang Syah selama 5 (lima) tahun sejak tahun 2012-2016 akan disajikan pada tabel di bawah ini :

Tabel : IV.7. Pendapatan Lain Yang Syah Kabupaten Lombok Timur Tahun 2012-2016 (jutaan rupiah)

\begin{tabular}{|c|c|c|c|c|}
\hline No. & Tahun & Anggaran & Realisasi & $\begin{array}{c}\text { Pertumbuhannya } \\
(\mathbf{\%})\end{array}$ \\
\hline 1 & 2012 & $37.763,93$ & $40.650,16$ & 8,11 \\
\hline 2 & 2013 & $85.115,24$ & $84.844,17$ & 108,72 \\
\hline 3 & 2014 & $107.275,48$ & $118.287,14$ & 40,48 \\
\hline 4 & 2015 & $118.287,14$ & $114.468,24$ & $-3,38$ \\
\hline 5 & 2016 & $135.437,12$ & $136.343,14$ & 19,29 \\
\hline \multicolumn{2}{r|}{ J u m l a h } & $\mathbf{4 8 3 . 8 7 8 , 9 1}$ & $\mathbf{4 1 8 . 5 9 2 , 8 5}$ & $\mathbf{1 7 3 , 2 2}$ \\
\hline & Rata-rata & $\mathbf{9 6 . 7 7 5 , 7 8}$ & $\mathbf{8 3 . 7 1 8 , 5 7}$ & $\mathbf{3 4 , 6 4}$ \\
\hline
\end{tabular}

Sumber : Kabupaten Lombok Timur dalam Angka 2012-2016, diolah.

Berdasarkan data tabel di atas dapat dijelaskan bahwa angka pertumbuhan Pendaatan Lain Yang Syah dilihat dari segi realisasi anggaran terhitung sejak tahun 2012 pertumbuhannya sebesar 8,11 persen, tahun 2013 meningkat menjadi sebesar 108,72 persen, tahun 2014 turun menjadi sebesar 40,48 persen, tahun 2015 turun lagi menjadi sebesar -3,38 persen dan tahun 2016 meningkat lagi menjadi sebesar 19,29 persen. Angka pertumbuhan tertinggi terjadi pada tahun 2013 yaitu sebesar 108,72 persen. Angka pertumbuhan rata-rata selama 5 (lima) tahun terhitung sejak tahun 2012-2016 mencapai 34,64 persen.

\subsection{Perkembangan Produk Domestik Regional Brutto}

Pendapatan Domestik Regional Brutto (PDRB) merupakan seluruh nilai tambah yang diciptakan dari berbagai aktivitas ekonomi di suatu daerah pada priode tertentu (satu tahun). Adapun dasar perhitungan PDB/PDRB sejak tahun 2014 menggunakan tahun dasar 
2010 dengan basis SNA 2008. Salah satu implikasi penggunaan SNA 2008 adalah perubahan nominal dan perubahan klasifikasi PDRB dari 9 sektor menjadi 17 katagori. PDRB atas dasar harga berlaku (ADH) Kabupaten Lombok Timur tahun 2016 mencapai 16,04 Trilyun rupiah. Angka ini menunjukkan peningkatan sekitar 1,5 Trilyun dari keadaan tahun 2015 yang mencapai 14,49 Trilyun rupiah. Jika kita ingin melihat struktur ekonomi suatu daerah dapat dilihat dari kontribusi masing-masing katagori terhadap pembentukan PDRB. Angka PDRB Lombok Timur menunjukkan bahwa katagori pertanian, kehutanan, dan perikanan memiliki kontribusi terbesar dalam pembentukan PDRB. Sebagai gambaran pada tahun 2016 lebih dari 1/4 (seper-empat) atau 28,35 persen PDRB LombokTimur berasal dari katagori pertanian. Meskipun dari tahun ke tahun persentase ini semakin mengecil dengan pergerakan yang relatif 'kecil/halus'. Secara umum menunjukkan perlahan namun pasti kecendrungan usaha sector pertanian semakin menurun/berkurang. Selain itu PDRB atas dasar harga konstan biasanya digunakan untuk melihat pertumbuhan ekonomi di suatu daerah. Dilihat dari segi laju pertumbuhan ekonomi Kabupaten Lombok Timur pada tahun 2016 mencapai 5,18 persen.

Selanjutnya untuk melihat bagaimana realisasi dan pertumbuhan PDRB (ADHK) dan (ADHB) Lombok Timur selama 5 (lima) tahun sejak tahun 2012-2016 akan disajikan pada tabel di bawah ini :

Tabel : IV.8. Pertumbuhan Ekonomi (PDRB) Kabupaten Lombok Timur Tahun 2012-2016 (jutaan rupiah)

\begin{tabular}{|c|c|c|c|c|}
\hline No. & Tahun & $\begin{array}{c}\text { PDRB Atas } \\
\text { Dasar } \\
\text { Harga Berlaku }\end{array}$ & $\begin{array}{c}\text { PDRB Atas Dasar } \\
\text { Harga Konstan } \\
\mathbf{2 0 1 0}\end{array}$ & $\begin{array}{c}\text { Pertumbuhan } \\
(\%)\end{array}$ \\
\hline 1 & 2012 & 10.706 .985 & 10.173 .536 & 4,85 \\
\hline 2 & 2013 & 11.531 .845 & 10.721 .723 & 5,51 \\
\hline 3 & 2014 & 12.875 .891 & 11.249 .937 & 4,79 \\
\hline 4 & 2015 & 14.240 .549 & 11.913 .551 & 5,91 \\
\hline 5 & 2016 & 16.044 .443 & 12.535 .284 & 5,18 \\
\hline & J u m l a h & $\mathbf{6 5 . 3 9 9 . 7 1 3}$ & $\mathbf{5 6 . 5 9 4 . 0 3 1}$ & $\mathbf{2 6 , 2 4}$ \\
\hline \multicolumn{2}{r}{ Rata-rata } & $\mathbf{1 3 . 0 7 9 . 9 4 2}$ & $\mathbf{1 1 . 3 1 8 . 8 0 6}$ & $\mathbf{5 , 2 5}$ \\
\hline
\end{tabular}

Sumber : Kabupaten Lombok Timur dalam Angka 2012-2016, diolah.

Berdasarkan data tabel di atas dapat dijelaskan bahwa angka pertumbuhan Ekonomi (PDRB) dilihat dari segi PDRB Atas Dasar Harga Berlaku dan PDRB Atas Dasar Harga Konstan 2010 terhitung sejak tahun 2012 pertumbuhannya sebesar 4,85 persen, tahun 2013 meningkat menjadi sebesar 5,51 persen, tahun 2014 turun menjadi sebesar 4,79 persen, tahun 2015 meningkat menjadi sebesar 5,91 persen dan tahun 2016 menjadi sebesar 5,18 persen. Angka pertumbuhan tertinggi terjadi pada tahun 2015 yaitu sebesar 5,91 persen. Angka pertumbuhan rata-rata selama 5 (lima) tahun terhitung sejak tahun 2012-2016 mencapai 5,25 persen.

\subsection{Perkembangan Kontribusi Dana Perimbangan Terhadap PDRB (ADHK)}

Selanjutnya untuk melihat bagaimana realisasi dan pertumbuhan Dana Perimbangan Terhadap PDRB Atas Dasar Harga Konstan Tahun 2010 (ADHK) Lombok Timur selama 5 (lima) tahun sejak tahun 2012-2016 akan disajikan pada tabel di bawah ini : 
Tabel : IV.9. Kontribusi Dana Perimbangan Terhadap Laju Pertumbuhan Ekonomi (PDRB) Atas Dasar Harga Konstan 2010 Kabupaten Lombok Timur Tahun 2012-2016 (jutaan rupiah).

\begin{tabular}{|c|c|c|c|}
\hline Tahun & Dana Perimbangan & $\begin{array}{c}\text { PDRB Atas Dasar } \\
\text { Harga Konstan 10 }\end{array}$ & $\begin{array}{c}\text { Persentase } \\
\text { Kontribusi (\%) }\end{array}$ \\
\hline 2012 & 1.021 .767 & 10.706 .985 & 9,55 \\
\hline 2013 & 1.129 .526 & 11.531 .845 & 9,79 \\
\hline 2014 & 1.243 .781 & 12.875 .891 & 9,66 \\
\hline 2015 & 1.335 .017 & 14.240 .549 & 9,37 \\
\hline 2016 & 1.749 .586 & 16.044 .443 & 10,91 \\
\hline Jumlah & $\mathbf{6 . 4 7 9 . 6 7 7}$ & $\mathbf{6 5 . 3 9 9 . 7 1 3}$ & $\mathbf{4 9 , 2 8}$ \\
\hline Rata-rata & $\mathbf{1 . 2 9 5 . 9 3 5}$ & $\mathbf{1 3 . 0 7 9 . 9 4 2}$ & $\mathbf{9 , 8 5}$ \\
\hline
\end{tabular}

Sumber : Kabupaten Lombok Timur dalam Angka 2012-2016, diolah.

Berdasarkan data tabel di atas dapat dijelaskan bahwa angka pertumbuhan Kontribusi Dana Perimbangan Terhadap Laju Pertumbuhan Ekonomi (PDRB) Atas Dasar Harga Berlaku Kabupaten Lombok Timur Tahun 2012-2016 sebagai berikut : terhitung sejak tahun 2012 pertumbuhan kontribusinya sebesar 9,55 persen, tahun 2013 meningkat menjadi sebesar 9,79 persen, tahun 2014 turun menjadi sebesar 9,66 persen, tahun 2015 turun lagi menjadi sebesar 9,37 persen dan tahun 2016 meningkat lagi menjadi sebesar 10,91 persen. Angka pertumbuhan tertinggi terjadi pada tahun 2016 yaitu sebesar 10,91 persen. Angka pertumbuhan rata-rata selama 5 (lima) tahun terhitung sejak tahun 20122016 mencapai 9,85 persen.

\subsection{Perkembangan Kontribusi Dana Perimbangan Terhadap PDRB (ADHB)}

Selanjutnya untuk melihat bagaimana pertumbuhan Kontribusi Dana Perimbangan Terhadap PDRB Atas Dasar Harga Berlaku (ADHB) Lombok Timur selama 5 (lima) tahun sejak tahun 2012-2016 akan disajikan pada tabel di bawah ini :

Tabel : IV.10. Kontribusi Dana Perimbangan Terhadap Laju Pertumbuhan Ekonomi

(PDRB) Atas Dasar Harga Berlaku Kabupaten Lombok Timur Tahun 2012-2016 (jutaan rupiah).

\begin{tabular}{|c|c|c|c|}
\hline Tahun & Dana Perimbangan & $\begin{array}{c}\text { PDRB Atas Dasar } \\
\text { Harga Berlaku }\end{array}$ & $\begin{array}{c}\text { Persentase } \\
\text { Kontribusi (\%) }\end{array}$ \\
\hline 2012 & 1.021 .767 & 10.173 .536 & 10,04 \\
\hline 2013 & 1.129 .526 & 10.721 .723 & 10,53 \\
\hline 2014 & 1.243 .781 & 11.249 .937 & 11,06 \\
\hline 2015 & 1.335 .017 & 11.913 .551 & 11,21 \\
\hline 2016 & 1.749 .586 & 12.535 .284 & 13,95 \\
\hline Jumlah & $\mathbf{6 . 4 7 9 . 6 7 7}$ & $\mathbf{5 6 . 5 9 4 . 0 3 1}$ & $\mathbf{5 6 , 7 9}$ \\
\hline Rata-rata & $\mathbf{1 . 2 9 5 . 9 3 5}$ & $\mathbf{1 1 . 3 1 8 . 8 0 6}$ & $\mathbf{1 1 , 3 6}$ \\
\hline
\end{tabular}

Sumber : Kabupaten Lombok Timur Dalam Angka 2012-2016, diolah.

Berdasarkan data tabel di atas dapat dijelaskan bahwa angka pertumbuhan Kontribusi Dana Perimbangan Terhadap Laju Pertumbuhan Ekonomi (PDRB) Atas Dasar Harga Berlaku Kabupaten Lombok Timur Tahun 2012-2016 sebagai berikut : terhitung sejak tahun 2012 pertumbuhan kontribusinya sebesar 10,04 persen, tahun 2013 meningkat menjadi sebesar 10,53 persen, tahun 2014 meningkat menjadi sebesar 11,06 persen, tahun 2015 meningkat lagi menjadi sebesar 11,21 persen dan tahun 2016 meningkat lagi menjadi sebesar 13,95 persen. Angka pertumbuhan tertinggi terjadi pada tahun 2016 yaitu sebesar 13,95 persen. Angka pertumbuhan rata-rata selama 5 (lima) tahun terhitung sejak tahun 2012-2016 mencapai 11,36 persen. 


\section{A. Kesimpulan}

\section{KESIMPULAN DAN SARAN}

1. Dampak pengalokasian dana perimbangan terhadap laju percepatan pertumbuhan ekonomi Kabupaten Lombok Timur terhitung sejak Tahun 2012-2016 sangat besar

2. Kontribusi dana perimbangan terhadap daya dorong laju percepatan pertumbuhan ekonomi Kabupaten Lombok Timur terhitung sejak Tahun 2012-2016 sangat significan

\section{B. SARAN-SARAN}

1. Mengingat besarnya peranan dana perimbangan baik yang bersumber dari dana alokasi umum (DAU) maupun yang bersumber dari dana alokasi khusus (DAK) terhadap pendapatan daerah dan pertumbuhan ekonomi (PDRB), maka pemerintah kabupaten Lombok Timur kedepannya tidak dapat secara terus menerus menggantungkan sumber pendapatan daerahnya dari dana perimbangan tersebut. Oleh karenanya mulai saat ini hendaknya pemerintah daerah harus sudah mulai berpikir tentang penggalian potensi sumber-sumber pendanaan dan pendapatan daerah lainnya agar tidak terlalu mengandalkan dana perimbangan sebagai sumber dana satu-satunya untuk melaksanakan pembangunan di berbagai sektor ekonomi.

2. Disamping optimalisasi penggalian potensi sumber dana, pemerintah kabupaten Lombok Timur hendaknya dapat melakukan intensifikasi perpajakan melalui penerapan efektivitas dan efisiensi sistem perpajakan serta pemberian reward and fanishment terhadap petugas pajak yang ada.

\section{DAFTAR PUSTAKA}

Anonim, 2000. "Pedoman Umum Penyusunan dan Pelaksanaan APBD Tahun Anggaran 2001". Surat Edaran Mendagri No. 903/2735/SJ.

2001. "Pedoman Umum Penyusunan dan Pelaksanaan APBD Tahun Anggaran 2002”. Surat Edaran Mendagri No. 903/2477/SJ.

2003. "Undang-Undang Republik Indonesia Nomor 17 tentang Keuangan

Negara”. Departemen Keuangan, Jakarta.

2004. "Undang-Undang Nomor 32 tentang Pemerintah Daerah". Penerbit CV.

Tamita Utama, Jakarta.

2004. "Undang-Undang Republik Indonesia Nomor 33 tentang Perimbangan

Keuangan antara Pemerintah Pusat dan Daerah". Penerbit CV. Tamita Utama, Jakarta.

2005. "Peraturan Pemerintah Nomor 58 tentang Pengelolaan Keuangan Daerah". Ditjen BAKD Depdagri, Jakarta.

2006. Permendagri Nomor : 13 tahun 2006 tentang Pedoman Pengelolaan

Keuangan Daerah, Direktorat Jendral Bina Administrasi Keuangan Daerah Depdagri, Jakarta.

2007. Peraturan Pemerintah Nomor : 58 tahun 2007 tentang Pedoman Pengelolaan Keuangan Daerah, Direktorat Jendral Bina Administrasi Keuangan Daerah Depdagri, Jakarta.

Bastian, Indra., 2001. "Manual Akuntansi Keuangan Pemerintah Daerah 2001”. Penerbit BPFE, Yogyakarta.

Halim, Abdul., 2002. “Akuntansi Keuangan Daerah”. Penerbit Salemba Empat, Jakarta. ., 2004. “Bunga Rampai Manajemen Keuangan Daerah”. Penerbit UPP AMP YKPN, Yogyakarta. 
Hariyadi, Jasagung, 1999, "Evaluasi Sisa Perhitungan Anggaran Pada Perhitungan APBD Kabupaten Belitung Tahun Anggaran 1991/1992 - 2000”, Tesis S-2, Program Pasca Sarjana Universitas Gadjah Mada, Yogyakarta (tidak dipublikasikan)

Hasbullah Yusuf, 2007, Anaisis Rasio Keuangan Pada Anggaran Pendapatan dan Belanja Daerah (APBD) Kabupaten Lombok Barat Tahun 2002-2005). Penerbit : Mataram Press Majalah Ilmiah ORIZA Universitas Mataram Vol.VI/No.2 April 2007.

2007, Analisis Kemampuan Keuangan Daerah Kota Mataram. Penerbit : Mataram Press Majalah Ilmiah ORIZA Universitas Mataram Vol.VI/No.3 Juli 2007.

Kama, 2002. "Evaluasi Akuntabilitas Kinerja Perencanaan APBD Tahun 2001 Bidang Pembangunan SDM di Lombok Tengah". Tesis S2, Program Pascasarja Magister Manajemen Fakultas Ekonomi Universitas Mataram (tidak dipublikasikan).

Kuncoro, Mudrajad., 2003. "Metode Riset Untuk Bisnis dan Ekonomi (Bagaimana meneliti \& menulis tesis)”. Penerbit Erlangga, Jakarta.

Luo, Huaping and Robert T Golembiewski., 1996. "Budget Deficits in China Calculations, Causes, and Impacts". The Pennsylvania State University, JXR11 @ PSU.EDU.

Mamesah D.J., 1995. “Sistem Administrasi Keuangan Daerah”. Penerbit PT. Gramedia Pustaka Utama, Jakarta.

Mardiasmo, MBA, Ak., 2000. Paradigma Baru Pengelolaan Keuangan Daerah Untuk Menyongsong Pelaksanaan Otonomi Daerah, Makalah Seminar HIMMEP, Yogyakarta.

2001. "Perencanaan Keuangan Publik Sebagai Suatu Tuntutan Dalam Pelaksanaan Pemerintahan Daerah Yang Bersih dan Berwibawa". Makalah, Jakarta.

, 2002. “Otonomi dan Manajemen Keuangan Daerah”. Serial Otonomi Daerah, Penerbit Andi Offset, Yogyakarta.

2004. "Akuntansi Sektor Publik". Penerbit Andi Offset, Yogyakarta.

Munir Dasril, Djuanda, Tangkilisan., 2004. "Kebijakan dan Manajemen Keuangan Daerah". Penerbit YPAPI, Yogyakarta.

Nazir Moh,Ph.D, 1983. Metode Penelitian, Penerbit : Ghalia Indonesia, Jakarta.

Suparmoko.M,MA,Ph.D, 2003. Keuangan Negara dalam Teori dan Praktik, Edisi 5, Penerbit BPFE, Yogyakarta

Sugiyono., 1999. "Metode Penelitian Bisnis". Penerbit CV. ALFABETA, Bandung.

Wesen Eugene F. Brigham J. Fred., 2001. "Dasar-dasar Manajemen Keuangan”. Edisi Kesembilan Jilid I.

Widodo, Hg, S.T., 1990. "Indikator Ekonomi Dasar Perhitungan Perekonomian Indonesia”. Kanisius, Yogyakarta.

William, N Dunn., 1998. “Analisis Kebijakan Publik”. Edisi Kedua, Gadjah Mada University Press, Yogyakarta. 
Halaman ini sengaja dikosongkan

62 | Analisis Dana Perimbangan Kaitannya Dengan Percepatan Laju Pertumbuhan ... 